\title{
Hubungan Motivasi Intrinsik, Persepsi Siswa, Motivasi Intrinsik dan Persepsi Siswa terhadap Pelajaran Fisika dan Prestasi Belajar Fisika Siswa Kelas X MIPA SMA
}

\author{
Kadek Dwi Cita Pusparini ${ }^{1}$, Ketut Suma ${ }^{2}$, Iwan Suswandi ${ }^{3}$ \\ ${ }_{1,2,3}$ Prodi Pendidikan Fisika Universitas Pendidikan Ganesha \\ e-mail: kadekdwi748@gmail.com, ketut.suma@undiksha.ac.id, Iwan.suswandi@undiksha.ac.id.
}

\begin{abstract}
Abstrak
Rendahnya prestasi belajar fisika siswa di SMA Negeri se-Kota Singaraja merupakan masalah utama yang dikaji dalam penelitian ini. Penelitian ini bertujuan untuk menganalisis hubungan antara motivasi intrinsik, persepsi siswa, motivasi dan persepsi siswa terhadap pelajaran fisika dan prestasi belajar fisika siswa Kelas X MIA SMA Negeri se-Kota Singaraja di tahun akademik 2019/2020. Jenis penelitian ini adalah ex-post facto dengan metode kuantitatif korelasional. Populasi sebanyak 830 orang dan sampel sebanyak 259 diambil dengan teknik proportional random sampling. Data diambil dengan menggunakan kuesioner dan tes prestasi. Teknis analisis data yang digunakan adalah analisis statistik deskriptif, uji asumsi, uji regresi linier satu prediktor, uji regresi ganda dua prediktor, dan pengujian hipotesis. Hasil penelitian menunjukkan bahwa motivasi intrinsik berada pada kategori tinggi, persepsi siswa terhadap pelajaran fisika berada pada kategori tinggi, dan prestasi belajar siswa berada pada kategori sedang. Kesimpulan penelitian ini adalah terdapat hubungan positif dan signifikan antara motivasi intrinsik dan persepsi siswa terhadap pelajaran fisika dan prestasi belajar.
\end{abstract}

Kata kunci: motivasi intrinsik, persepsi siswa terhadap pelajaran fisika, prestasi belajar

\begin{abstract}
The low of learning achievement of SMANs' students in Singaraja was the main problem studied in this research. This study aimed at analyzing the relationship between intrinsic motivation, student perception, intrinsic motivation and student perception towards the physics lesson and the physics learning achievement of $10^{\text {th }}$ grade students in SMANs in Singaraja in academic year 2019/2020. The type of this study was ex-post facto with correlational quantitative methods. The population of 830 students and the sample of 259 students were taken by proportional random sampling techniques. The data were collected by questionnaire and performance tests. The analysis technics used for analyzing data were descriptive statistical analysis, assumption test, one predictor linear regression test, two predictors double regression test, and hypothesis testing. The results of this study show that the intrinsic motivation is in the high category, the students' perception toward physics lessons are in the high category, and the students' learning achievement are in the medium category. The conclusion of this research is that there is a positive and significant relationship between intrinsic motivation and student perception toward the physics lesson and learning achievement.
\end{abstract}

Keywords: intrinsic motivation, students' perceptions of physics lessons, learning achievement

\section{PENDAHULUAN}

Kemajuan suatu negara sangat bergantung kepada kualitas sumber daya manusianya. Salah satu faktor yang menentukan kualitas sumber daya manusia adalah pendidikan. Melalui pendidikan akan terbentuk kepribadian yang baik, keagamaan yang baik, dan ahlak mulia pada diri seseorang (Kemendikbud RI, 2003). Pemerintah telah banyak melakukan upaya untuk memperbaharui pendidikan di Indonesia, salah satunya adalah pergantian kurikulum. Kurikulum 2013 adalah kurikulum yang dibuat oleh pemerintah untuk menyiapkan sumber daya manusia yang berkualitas. Kurikulum 2013 diharapkan mampu menjadikan peserta didik yang kreatif, inovatif, produktif, afektif, dan berkontribusi pada negara dan peradaban dunia (Permendikbud, 2013).

Pemerintah mengharapkan prestasi belajar di Indonesia terus meningkat sehingga terus terjadi perbaruan dalam pendidikan Indonesia. Namun fakta di lapangan menunjukkan 
bahwa prestasi belajar di Indonesia masih tergolong rendah. Khusus dalam bidang sains, Organization for Economic Co-Operation and Development (OECD) tahun 2019 menyatakan bahwa Indonesia mendapat peringkat ke-70 dari 78 negara di dunia. Peringkat yang jauh di bawah mengidentifikasikan bahwa pendidikan di Indonesia masih tergolong rendah. Fakta lain mengenai rendahnya pendidikan di Indonesia diketahui dari beberapa hasil penelitianpenelitian sebelumnya. Penelitian yang dilakukan oleh Diana (2018), menyatakan bahwa prestasi belajar SMA Negeri di Kecamatan Nusa Penida masih tergolong rendah. Rendahnya prestasi belajar siswa diketahui dari nilai rata-rata siswa saat menjawab tes prestasi belajar. Selain itu, penelitian yang dilakukan oleh Utami (2019) menyatakan bahwa prestasi belajar di SMA Negeri se-Kota Singaraja masih tergolong rendah. Rendahnya prestasi belajar diketahui dari hasil tes prestasi belajar yang belum mencapai kriteria KKM yang ditentukan. Fakta ini menunjukkan adanya kesenjangan antara harpan dan kenyataan di lapangan. Harapan pendididikan yang berkualitas masih jauh karena kenyataannya kualitas pendidikan masih rendah.

Menurut Slameto (2003), terdapat dua faktor yang memengaruhi prestasi belajar siswa, yaitu faktor intrinsik dan ekstrinsik. Faktor intrinsik berasal dari dalam diri seperti motivasi belajar siswa, minat siswa terhadap pelajaran, persepsi siswa terhadap pelajaran, dan tingkat itelegensi. Faktor ekstrinsik berasal dari luar seperti faktor keluarga, faktor sekolah, dan faktor masyarakat. Faktor intrinsik lebih berperan dalam meningkatkan gairah belajar karena siswa memiliki minat tersendiri untuk belajar. Menurut Moekijat, (2002), daya pendorong atau perangsang seseorang dalam melakukan seduatu adalah motivasi. Siswa yang termotivasi untuk belajar akan mendorong siswa untuk melakukan kegiatan belajar. Ada dua motivasi yaitu motivasi intrinsik dan motivasi ekstrinsik. Motivasi intrinsik merupakan keinginan seorang individu untuk melakukan sesuatu. Orang yang termotivasi untuk belajar secara intrinsik akan memprioritaskan belajar hampir di atas kepentingan lainnya (Moekijat, 2002).

Motivasi intrinsik merupakan motivasi yang dimiliki oleh seseorang tanpa adanya pengaruh dari orang lain (Azka, 2019). Motivasi intrinsik merupakan prilaku yang timbul karena keinginan sendiri, dorongan, dan minat dari diri sendiri (Arief, 2016). Menurut Suprihatin (2015), kemauan yang bersumber dari diri sendiri akan menentukan kualitas perilaku yang ditampilkan seseorang dalam konteks belajar maupun yang lainnya.

Motivasi yang timbul dari dalam diri seseorang tanpa adanya pengaruh dari orang lain merupakan motivasi intrinsik (Azka, 2019). Suatu perilaku individu yang dikarenakan oleh dorongan, minat, dan timbul karena keinginan sendiri disebut motivasi intrinsik (Arief, 2016). Menurut Suprihatin (2015), kemauan yang bersumber dari diri sendiri akan menentukan kualitas perilaku yang ditampilkan seseorang dalam konteks belajar maupun yang lainnya. Motivasi ekstrinsik adalah motivasi yang dirangsang atau perlu adanya dorongan terlebih dahulu. Motivasi ekstrinsik dapat berupa hadiah dari orang tua jika mendapat prestasi yang tinggi. Siswa yang termotivasi secara ekstrinsik akan melakukan berbagai cara untuk mendapatkannya walaupun harus mencontek dan membeli kunci jawaban. Sehingga, dapat dikatakan bahwa motivasi intrinsik lebih berpengaruh dari pada motivasi ekstrinsik, karena lebih memprioritaskan belajar daripada kepentingan lainnya.

Selain motivasi, persepsi juga merupakan salah satu faktor intrinsik siswa. Persepsi sudah terbentuk dari awal mengenal suatu pelajaran di sekolah. Seseorang dapat memberikan tanggapan mengenai baik buruk atau positif negatif dari informasi yang diterima (Marupa, 2017). Oleh karena itu, peserta didik diharapkan mempunyai persepsi yang baik terhadap pelajaran. Namun, kenyataan di lapangan masih banyak peserta didik mempunyai persepsi kurang baik terhadap pelajaran. salah satunya adalah pelajaran fisika. Pelajaran fisika sering dipersepsikan sebagai pelajaran yang sulit (Prasetyowati, 2017). Pandangan siswa yang buruk terhadap suatu pelajaran mengakibatkan siswa malas belajar. Sementara, pandangan siswa yang baik terhadap pelajaran dapat membangkitkan semangat siswa untuk mempelajari pelajaran. Oleh sebab itu, persepsi merupakan salah satu faktor penentu keberhasilan pendidikan. Kurniawan (2016) menyatakan pandangan siswa mengenai pelajaran fisika adalah salah satu faktor intrinsik yang memengaruhi prestasi belajar 
fisikanya. Menurut Mawarnia (2017), arah persepsi yang dimiliki siswa dapat menentukan menarik atau tidaknya suatu pelajaran. Siswa menganggap pelajaran fisika sulit dan tidak menarik untuk diminati siswa sehingga menyebabkan hasil belajar rendah (Arif, 2016). Semangat belajar yang tinggi dapat mengkondisikan siswa untuk terus perhatian dalam proses pembelajaran (Kurniawan et al., 2016). Ditelusuri lebih lanjut, khususnya pada pelajaran fisika, baik motivasi intrinsik maupun persepsi siswa terhadap pelajaran fisika sama-sama memengaruhi prestasi belajar siswa fisika. Beberapa penelitian sebelumnya menunjukkan adanya hubungan yang positif dan signifikan antara motivasi intrinsik terhadap prestasi belajar. Hasil penelitian (Aini et. al., 2017; Akhtar et. al., 2017; Saki et.al., 2018; Bosch et. al., 2019) menunjukkan bahwa semakin tinggi motivasi intrinsik terhadap pelajaran maka prestasi siswa juga semakin tinggi. Sedangkan semakin rendah motivasi intrinsik siswa terhadap pelajaran maka prestasi belajar siswa cenderung rendah. Selain itu, terdapat penelitian yang dilakukan oleh (Lestari et. al., 2017; Mawarnia, 2017; Prasetyowati et. al., 2017; Pratama et. al., 2018; Prasetyowati et. al., 2017; Albadi et. al., 2018; Suprapto., 2019) menunjukkan terdapat hubungan positif dan signifikan antara persepsi terhadap pelajaran fisika dengan prestasi belajar fisika siswa. Hasil penelitian ini mengartikan bahwa semakin baik persepsi siswa terhadap pelajaran maka prestasi belajar yang dicapai juga semakin baik. Adanya kesenjangan antara harapan dan kenyataan dalam pendidikan IPA di atas dan bukti-bukti tentang hubungan motivasi instrinsik, persepsi dan hasil belajar, mendorong peneliti untuk melakukan studi tentang hubungan antara motivasi intrinsik, persepsi siswa dengan prestasi belajar fisika pada siswa kelas X MIPA SMA Negeri se-Kota Singaraja Tahun Ajaran 2019/2020.

Permasalahan pokok yang dikaji dalam penelitian ini adalah: (1) Apakah terdapat hubungan antara motivasi intrinsik dan prestasi belajar fisika siswa Kelas X MIPA SMA Negeri se-Kota Singaraja?; (2) Apakah terdapat hubungan antara persepsi siswa terhadap pelajaran fisika dan prestasi belajar fisika siswa Kelas X MIPA SMA Negeri se-Kota Singaraja?; dan (3) Apakah terdapat hubungan secara bersama-sama antara motivasi intrinsik dan persepsi siswa terhadap pelajaran fisika dengan prestasi belajar fisika siswa Kelas X MIPA SMA Negeri se-Kota Singaraja?. Dengan demikian, tujuan penelitian ini adalah: (1) Menganalisis hubungan antara motivasi intrinsik dan prestasi belajar fisika siswa Kelas X MIPA SMA Negeri se-Kota Singaraja; (2) Menganalisis hubungan antara persepsi siswa terhadap pelajaran fisika dan prestasi belajar fisika siswa Kelas X MIPA SMA Negeri se-Kota Singaraja; (3) Menganalisis hubungan secara bersama-sama antara motivasi intrinsik dan persepsi siswa terhadap pelajaran fisika dengan prestasi belajar fisika siswa Kelas X MIPA SMA Negeri se-Kota Singaraja.

\section{METODE}

Penelitian ini menggunakan metode penelitian kuantitatif korelasional dengan desain expost facto. Desain ex-post facto digunakan dalam penelitian yang tidak mempunyai kontrol langsung terhadap variabel-variabel bebas (Siregar, 2011). Adapun variabel yang dilibatkan dalam penelitian ini adalah variabel bebas, yaitu motivasi intrinsik dan persepsi siswa terhadap pelajaran fisika, dan variabel terikatnya, yaitu prestasi belajar siswa.

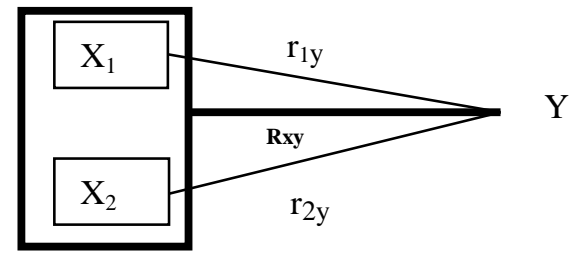

Gambar 1 Desain Penelitin (Santyasa, 2018)

Penelitian ini dilakukan di SMA Negeri se-Kota Singaraja dengan populasi penelitian adalah seluruh siswa kelas X MIPA yang berjumlah 830 siswa. Dari populasi itu 259 siswa ditetapkan sebagai sampel yang diambil dengan teknik proportional random sampling. 
Instrumen yang digunakan adalah kuesioner dan tes prestasi belajar. Data tentang motivasi intrinsik dan persepsi siswa terhadap pelajaran fisika dikumpulkan dengan kuesioner. Data tentang prestasi belajar fisika dikumpulkan dengan tes prestasi belajar. Penentuan skor untuk item-item kuesioner menggunakan skala likert, sedangkan skor untuk item-item prestasi belajar ditentukan dengan menggunakan skala non dikotomi. Untuk menguji hubungan antara motivasi intrinsik, persepsi siswa terhadap pelajaran fisika, dan prestasi belajar fisika menggunakan teknik analisis korelasi dan regresi ganda yang perhitungannya dibantu dengan SPSS 2.4. uji hipotesis dilakukan pada taraf signifikansi 0,05 . Instrument penelitian secara lebih lengkap dengan aspek-aspeknya diuraikan pada Tabel 1.

Tabel 1. Aspek-aspek Masing-masing Instrumen Penelitian

\begin{tabular}{clcc}
\hline No & \multicolumn{1}{c}{ Motivasi Intrinsik } & $\begin{array}{c}\text { Persepsi } \\
\text { Siswa }\end{array}$ & $\begin{array}{c}\text { Prestasi } \\
\text { Belajar }\end{array}$ \\
\hline 1 & Hasrat dan keinginan berhasil & Kognisi & Pengetahuan \\
2 & Dorongan dan kebutuhan dalam belajar & Afeksi & Proses Kognitif \\
3 & Harapan dan cita-cita & Konasi & \\
\hline
\end{tabular}

Konsistensi internal kuesioner motivasi antara $r=0,564-0,801$. Konsistensi internal butir persepsi siswa terhadap pelajaran fisika antara $r=0,382-0,774$. Indeks realibilitas kuesioner motivasi intrinsik $r=0,950$. Indeks realibilitas kuesioner persepsi siswa terhadap pelajaran fisika $r=0,949$. Konsistensi internal butir tes prestasi belajar $r=0,379-0,705$. Tingkat Kesukaran Butir tes antara 0,356 sampai dengan 0,760, Indeks Daya Beda antara 0,219 sampai dengan 0,563. Indeks realibilitas tes prestasi belajar fisika $r=0,745$.

Data tentang motivasi instrinsik, persepsi terhadap mata pelajara fisika dan hasil belajar analisis dengan teknik deskritif analisis korelasi, dan analisi regresi ganda. Teknik deskriptif digunakan untuk mendeskripsikan rerata dan standard deviasi. Analisis deskriptif menggunakan pedoman Penilaian Acuan Patokan (PAP). Kategori sangat rendah dari (0 39), rendah dari (40-54), sedang dari (55-69), tinggi dari (70-84), dan sangat tinggi dari (85100 ). Analisis korelasi digunakan untuk mengukur pengaruh variable bebas dan variable terikat, dan teknik regresi ganda digunakan untuk mengukur pengaruh dari dua variable bebas terhadap variable terikat.

Sebelum analisis korelsasi dan regresi dilakukan, terlebih dahulu dilakukan pengujian persyaratan analsis yang meliputi (1) Uji Normalitas sebaran data, (2) linieritas garis regresi, (3) multikolinieritas model regresi, (4) autokorelasi model regresi, dan (5) uji heteroskedastisitas. Normalitas sebaran data menggunakan uji Kolmogorov Smirnov (KS) dengan nilai signifikansi two tailed. Nilai signifikansi $>0,05$ artinya berdistribusi normal dan sebaliknya. Linearitas garis regresi menggunakan uji linearitas satu prediktor dan linearitas dua prediktor. Deviasi dari linearitas yang signifikansinya $>0,05$ artinya terdapat hubungan yang linier dan signifikan antara prediktor dan kriterium. Multikolinieritas model regresi menggunakan uji multikolonieritas. Nilai Tolerance $>0,10$ dan VIF $<10,00$ artinya tidak terjadi gejala multikolonieritas pada model regresi. Autokorelasi model regresi menggunakan uji autokorelasi dan berpedoman pada nilai Durbin Watson. Nilai Durbin Watson yang lebih besar dari du atau < 4 - du artinya tidak terdapat autokorelasi pada model regresi. Heteroskedastisitas menggunakan uji Scatterplot yaitu dengan melihat penyebabaran titiktitik. Scatterplot yang baik adalah tidak mempunyai pola bergelombang dan tidak mengumpul. Semua perhitungan dibantu dengan SPSS 2.4. Hasil analisis uji persyaratan yang telah dilakukan menyatakan bahwa semua kriteria telah terpenuhi. Sehingga analisis korelasi dan regresi dapat dilakukan.

Pada penelitian ini diajukan 3 hipotesis yaitu: (1) Terdapat hubungan positif antara motivasi intrinsik dan prestasi belajar fisika siswa kelas X MIPA SMA Negeri se-Kota Singaraja; (2) Terdapat hubungan positif antara persepsi siswa terhadap pelajaran fisika dan 
prestasi belajar fisika siswa kelas X MIPA SMA Negeri se-Kota Singaraja; (3) Terdapat hubungan positif secara bersama-sama antara motivasi intrinsik dan persepsi siswa terhadap pelajaran fisika siswa kelas X MIPA SMA Negeri se-Kota Singaraja.

\section{HASIL DAN PEMBAHASAN}

Tabel 1 menunjukkan ringkasan hasil analisis deskriptif skor motivasi intrinsik, persepsi siswa terhadap pelajaran fisika dan hasil belajar fisika.

Tabel 2. Deskripsi Umum Motivasi Intrinsik, Persepsi Siswa Terhadap Pelajaran Fisika Siswa.

\begin{tabular}{lrrr} 
Statistik & $\begin{array}{c}\text { Motivasi } \\
\text { Intrinsik }\end{array}$ & $\begin{array}{c}\text { Persepsi Siswa } \\
\text { terhadap } \\
\text { Pelajaran Fisika }\end{array}$ & $\begin{array}{c}\text { Prestasi } \\
\text { Belajar Fisika }\end{array}$ \\
\hline Mean & 66,44 & 65,37 & 61,94 \\
Standar Deviasi & 13,46 & 16,62 & 16,17 \\
\hline
\end{tabular}

Dari Tabel 2, tampak bahwa rata-rata skor motivasi intrinsik $\overline{X_{1}}=66,44(\mathrm{SD}=13,46)$, yang termasuk pada kategori sedang. Sementara itu, rata-rata skor persepsi siswa terhadap pelajaran fisika $\overline{X_{2}}=65,37(S D=16,62)$, yang termasuk pada kategori sedang. Rata-rata skor prestasi belajar fisika adalah $\bar{Y}=61,94(\mathrm{SD}=16,17)$, yang termasuk pada kategori sedang.

Distribusi frekuensi skor motivasi intrisik, persepsi siswa terhadap pelajaran fisika, dan prestasi belajar fisika ditunjukkan pada Tabel 3, Tabel 4, dan Tabel 5.

Tabel 3. Distribusi Frekuensi Skor Motivasi Intrinsik

\begin{tabular}{clrr}
\hline Interval & Kategori & Frekuensi Siswa & Persentase (\%) \\
\hline $85-100$ & Sangat Tinggi & 47 & 18,15 \\
$70-84$ & Tinggi & 69 & 26,64 \\
$55-69$ & Sedang & 77 & 29,73 \\
$40-54$ & Rendah & 51 & 19,69 \\
$0-39$ & Sangat Rendah & 15 & 5,79 \\
& Jumlah & $\mathbf{2 5 9}$ & $\mathbf{1 0 0 , 0 0}$ \\
\hline
\end{tabular}

Tabel 4. Distribusi Frekuensi Persepsi Siswa terhadap pelajaran Fisika

\begin{tabular}{clrr}
\hline Interval & Kategori & Frekuensi Siswa & Persentase (\%) \\
\hline $85-100$ & Sangat Tinggi & 29 & 11,20 \\
$70-84$ & Tinggi & 76 & 29,34 \\
$55-69$ & Sedang & 83 & 32,05 \\
$40-54$ & Rendah & 58 & 22,39 \\
& Sangat & 13 & 5,02 \\
$0-39$ & Rendah & $\mathbf{2 5 9}$ & $\mathbf{1 0 0 . 0 0}$ \\
\cline { 2 - 3 } & Jumlah & Tabel 5. Distribusi Frekuensi Prestasi Belajar Fisika
\end{tabular}




\begin{tabular}{clrr}
\hline Interval & Kategori & $\begin{array}{c}\text { Frekuensi } \\
\text { Siswa }\end{array}$ & Persentase (\%) \\
\hline $85-100$ & Sangat Tinggi & 14 & 5,41 \\
$70-84$ & Tinggi & 67 & 25,87 \\
$55-69$ & Sedang & 96 & 37,07 \\
$40-54$ & Rendah & 71 & 27,41 \\
$0-39$ & Sangat Rendah & 11 & 4,25 \\
& Jumlah & $\mathbf{2 5 9}$ & $\mathbf{1 0 0}$ \\
\hline
\end{tabular}

Uji asumsi harus dilakukan terlebih dahulu sebelum melakukan uji regresi agar statistik parametrik dapat diterapkan. Uji normalitas dilakukan terlebih dahulu untuk mengetahui apakah data berdistribusi normal atau tidak, berikut hasil analisisnya dalam autput SPSS 2.4.

One-Sample Kolmogorov-Smirnov Test

\begin{tabular}{|c|c|c|c|c|}
\hline & & $\begin{array}{c}\text { Prestasi } \\
\text { Belajar Fisika } \\
\text { Siswa }\end{array}$ & $\begin{array}{l}\text { Motivasi } \\
\text { Intrinsik }\end{array}$ & $\begin{array}{l}\text { Persepsi Siswa } \\
\text { Terhadap } \\
\text { Pelajaran Fisika }\end{array}$ \\
\hline$\overline{\mathrm{N}}$ & & 259 & 259 & 259 \\
\hline \multirow[t]{2}{*}{ Normal Parameters $\mathrm{a}, \mathrm{b}$} & Mean & 61.94 & 66.44 & 65.37 \\
\hline & Std. Deviation & 13.464 & 16.623 & 16.167 \\
\hline Most Extreme & Absolute & .051 & .050 & .043 \\
\hline \multirow[t]{2}{*}{ Differences } & Positive & .048 & .040 & .040 \\
\hline & Negative & -.051 & -.050 & -.043 \\
\hline Test Statistic & & .051 & .050 & .043 \\
\hline Asymp. Sig. (2-tailed) & & $.200^{c, d}$ & $.200^{c, d}$ & $.200^{c, d}$ \\
\hline
\end{tabular}

Output SPSS uji normalitas sebaran data menunjukkan ketiga variabel berdistribusi normal sehingga uji selanjutnya dapat dilakukan. Uji linearitas kemudian dilakukan, hasil uji linearitas disajikan pada Tabel 6.

Tabel 6. Hasil Uji Linearitas

\begin{tabular}{|c|c|c|c|c|c|c|c|}
\hline No & $\begin{array}{c}\text { Hubungan } \\
\text { Variabel }\end{array}$ & & pesifikasi & Jumlah Kuadrat & df & $\mathbf{F}$ & Sig. \\
\hline \multirow{5}{*}{1} & \multirow{5}{*}{$\begin{array}{l}\text { Prestasi } \\
\text { Belajar } \\
\text { Fisika Siswa } \\
\text { * Motivasi } \\
\text { Intrinsik }\end{array}$} & \multirow{3}{*}{$\begin{array}{l}\text { Antar } \\
\text { Grup }\end{array}$} & Gabungan & 31292.656 & 65 & 6.004 & 0.000 \\
\hline & & & Linearitas & 24668.310 & 1 & 307.630 & 0.000 \\
\hline & & & $\begin{array}{l}\text { Deviasi dari } \\
\text { Linearitas }\end{array}$ & 6624.346 & 64 & 1.291 & 0.095 \\
\hline & & \multicolumn{2}{|c|}{ Dalam Grup } & 15476.356 & 193 & & \\
\hline & & Total & & 46769.012 & 258 & & \\
\hline \multirow{5}{*}{2} & \multirow{5}{*}{$\begin{array}{l}\text { Prestasi } \\
\text { Belajar } \\
\text { Fisika Siswa } \\
\text { * Persepsi } \\
\text { Siswa } \\
\text { Terhadap } \\
\text { Pelajaran } \\
\text { Fisika }\end{array}$} & & Gabungan & 36494.135 & 62 & 11.228 & 0.000 \\
\hline & & Antar & Linearitas & 33131.359 & 1 & 632.002 & 0.000 \\
\hline & & Grup & $\begin{array}{l}\text { Deviasi dari } \\
\text { Linearitas }\end{array}$ & 3362.777 & 61 & 1.052 & 0.390 \\
\hline & & \multicolumn{2}{|c|}{ Dalam Grup } & 10274.876 & 196 & & \\
\hline & & \multicolumn{2}{|l|}{ Total } & 46769.012 & 258 & & \\
\hline
\end{tabular}

Berdasarkan Tabel 6, nilai deviasi linearitas pada masing-masing hubungan variabel > 0,05 sehingga terdapat hubungan yang linier antar variabel bebas dan variabel terikat. Nilai signifikansi pada linearitas pada maisng-masing hubungan variabel $<0,05$ sehingga 
koefisien arah regresi berarti. Uji multikolinieritas kemudian dilakukan, hasil pengujian disajikan pada Tabel 7.

Tabel 7. Hasil Uji Multikolinieritas

\begin{tabular}{lcc}
\hline \multicolumn{1}{c}{ Variasi Bebas } & \multicolumn{2}{c}{ Satistik Collinearity } \\
& Toleransi & VIF \\
\hline Motivasi Intrinsik $\left(\mathrm{X}_{1}\right)$ & 0,369 & 2,710 \\
Persepsi Siswa terhadap Pelajaran Fisika $\left(\mathrm{X}_{2}\right)$ & 0,369 & 2,710 \\
\hline
\end{tabular}

Berdasarkan Tabel 7. Nilai toleransi $>0,10$ dan nilai VIF $<10,00$ sehingga tidak terjadi gejala multikolonieritas pada model regresi. Uji autokorelasi kemudian dilakukan, hasil pengujian disajikan pada Tabel 8 dan dan tabel statistic Durbin-Watson disajikan pada tabel 9.

Tabel 8. Ringkasan Hasil Uji Autokorelasi

\begin{tabular}{|c|c|c|}
\hline \multicolumn{2}{|c|}{ Variabel } & \multirow{2}{*}{$\begin{array}{l}\text { Nilai Durbin- } \\
\text { Watson }\end{array}$} \\
\hline Vareabel Bebas & Variabel Terikat & \\
\hline $\begin{array}{l}\text { Motivasi Intrinsik (X1) } \\
\text { Persepsi Siswa terhadap } \\
\text { Pelajaran Fisika (X2) }\end{array}$ & $\begin{array}{l}\text { Prestasi Belajar Fisika Siswa } \\
\text { (Y) }\end{array}$ & 1,929 \\
\hline
\end{tabular}

Tabel 9. Tabel Statistik Durbin-Watson dengan $\alpha=0,05$

\begin{tabular}{cccccc}
\hline \multirow{2}{*}{ Jumlah Data (n) } & \multicolumn{4}{c}{ Jumlah Variabel Bebas $(\mathbf{k}=\mathbf{2})$} \\
& $\mathbf{d u}$ & $\mathbf{4}-\mathbf{d u}$ & $\mathbf{d L}$ & $\mathbf{4}-\mathbf{d L}$ \\
\hline 259 & 1,80075 & 2,19925 & 1,78469 & 2,21531 \\
\hline
\end{tabular}

Berdasarkan Tabel 9, nilai Durbin-Watson lebih besar dari batas atas du yang bernilai 1,80075 dan kurang dari $(4-\mathrm{du}) 4-1,80075=2,19925$ sehingga tidak terdapat gejala autokorelasi pada model regresi. Uji heteroskedastisitas kemudian dilakukan, hasil pengujian berupa Scatterplot disajikan pada Gambar 2.

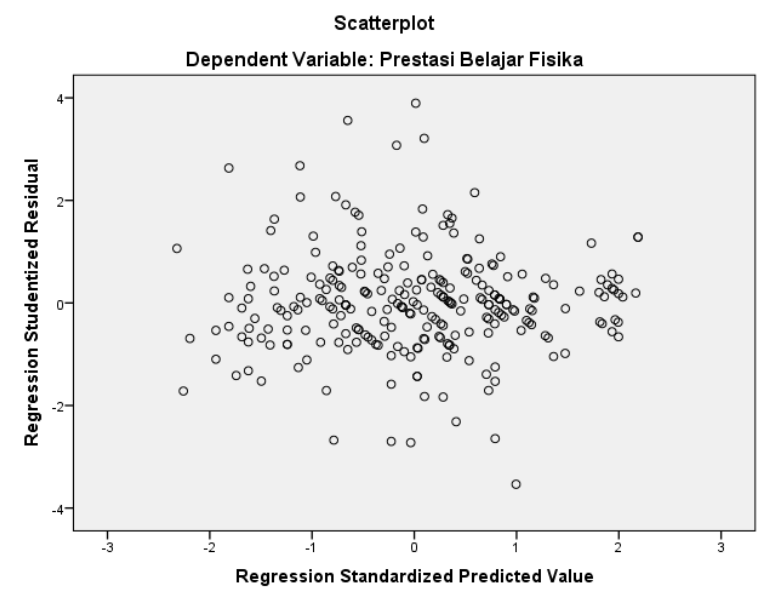

Gambar 2. Scatterplot Error Varians 
Berdasarkan Gambar 2, diketahui bahwa penyebaran titik-titik berada di atas dan di bawah atau di sekitar angka 0, tidak mengumpul di atas atau di bawah saja, dan penyebarannya tidak membentuk pola bergelombang. Sehingga dapat disimpulkan bahwa model pada penelitian ini terbebas dari asumsi heteroskedastisitas dan model regresi yang baik dan ideal dapat terpenuhi.

Berdasarkan uji asumsi yang telah terpenuhi, maka uji hipotesis dapat dilakukan. Ringkasan hasil uji regresi linier satu prediktor dan uji regresi ganda dua prediktor disajikan pada Tabel

Tabel 10. Ringkasan Hasil Uji Regresi

\begin{tabular}{|c|c|c|c|c|c|c|c|c|c|}
\hline $\begin{array}{c}\text { Pasangan } \\
\text { Variabel }\end{array}$ & $\begin{array}{c}\text { Persamaan } \\
\text { Regresi }\end{array}$ & $\mathbf{F}_{\text {hitung }}$ & $F_{\text {tabel }}$ & Sig. & $\mathbf{R}$ & $\mathbf{R}^{2}$ & $\begin{array}{c}K \\
(\%)\end{array}$ & SE (\%) & SR (\%) \\
\hline$X_{1} \rightarrow Y$ & $\begin{array}{l}\hat{Y}=22,853+ \\
0,588 X_{1}\end{array}$ & 36 & 32 & 0 & ,726 & 527 & 52,7 & 2,67 & 7,67 \\
\hline $\mathrm{X}_{2} \rightarrow \mathrm{Y}$ & $\begin{array}{l}\hat{Y}=16,121+ \\
0,701 \mathrm{X}_{2}\end{array}$ & 624,36 & 1,9692 & 0,000 & 0,842 & 0,708 & 70,8 & 9,03 & 82,33 \\
\hline $\begin{array}{l}X_{1} \text { dan } X_{2} \\
\rightarrow Y\end{array}$ & $\begin{array}{l}\hat{Y}=14,468+ \\
0,127 \mathrm{X}_{1}+ \\
0,598 \mathrm{X}_{2}\end{array}$ & 324,97 & 1,9693 & 0,000 & 0,847 & 0,717 & 71,7 & 71,70 & 100 \\
\hline
\end{tabular}

Berdasarkan Tabel 10, uji regresi antara prediktor $X_{1}$ (motivasi intrinsik) dan kriterium $Y$

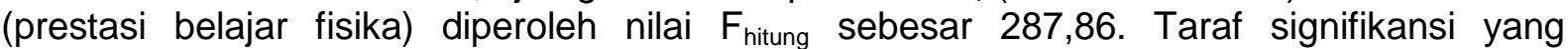
digunakan adalah $5 \%$ dengan derajat kebebasan pembilang 1 dan derajat kebebasan penyebut 259 diperoleh nilai $F_{\text {tabel }}$ sebesar 1,9692. Jika $F_{\text {hitung }}$ dibandingkan dengan $F_{\text {tabel }}$ maka didapatkan $F_{\text {hitung }}>F_{\text {tabel }}$ (Ho ditolak dan Ha diterima). Hasil ini mengartikan terdapat hubungan positif antara motivasi intrinsik dan prestasi belajar fisika siswa kelas X MIPA SMA Negeri se-Kota Singaraja. Nilai $R^{2}$ ( $R$ Square) sebesar 0,527 menunjukkan bahwa $52,7 \%$ dari variabel prestasi belajar fisika siswa dapat dijelaskan oleh perubahan variabel motivasi intrinsik. Sumbangan efektif sebesar $12,91 \%$ menyatakan bahwa sumbangan prediktor $X_{1}$ terhadap kriterium $Y$ hanya sebesar $12,67 \%$. Sisanya sebesar $87,33 \%$ merupakan akumulasi sumbangan dari variabel persepsi siswa terhadap pelajaran fisika dan variabel-variabel lain yang tidak dikaji dalam penelitian ini. Variasi kontribusi dari variabel prestasi belajar fisika dapat dijelaskan oleh variabel motivasi intrinsik melalui persamaan regresi $\hat{Y}=22,853+$ $0,588 X_{1}$. Persamaan regresi ini mengartikan bahwa setiap pertambahan nilai prediktor $X_{1}$ sebesar satu satuan maka nilai kriterium $Y^{\wedge}$ akan bertambah sebesar 0,588 satuan. Persamaan regresi ini mengartikan bahwa tinggi rendahnya prestasi belajar fisika siswa disebabkan oleh motivasi intrinsik siswa yang diprediksi dengan persamaan regresi tersebut.

Berdasarkan Tabel 10, uji regresi antara prediktor $\mathrm{X}_{2}$ dan kriterium $\mathrm{Y}$ diperoleh nilai $F_{\text {hitung }}$ sebesar 624,36 . Taraf signifikansinya adalah $5 \%$ dengan derajat kebebasan pembilang 1 dan derajat kebebasan penyebut 259 diperoleh nilai $F_{\text {tabel }}$ sebesar 1,9692. Jika $F_{\text {hitung }}$ dibandingkan dengan $F_{\text {tabel }}$ maka didapatkan $F_{\text {hitung }}>F_{\text {tabel }}$ (Ho ditolak dan Ha diterima). Hasil ini mengartikan terdapat hubungan positif antara persepsi siswa terhadap pelajaran fisika dan prestasi belajar fisika siswa kelas X MIPA SMA Negeri se-Kota Singaraja. Nilai $R^{2}(R$ Square) sebesar 0,708 menunjukkan bahwa 70,8\% dari variabel prestasi belajar fisika siswa dapat dijelaskan oleh perubahan variabel persepsi siswa terhadap pelajaran fisika. Sumbangan sebesar $59,03 \%$ menyatakan bahwa sumbangan prediktor $\mathrm{X}_{2}$ terhadap kriterium $Y$ hanya sebesar $59,03 \%$. Sisanya sebesar $40,97 \%$ merupakan akumulasi sumbangan dari variabel motivasi intrinsik dan variabel-variabel lain yang tidak dikaji dalam penelitian ini. Variasi kontribusi dari variabel prestasi belajar fisika dapat dijelaskan oleh variabel persepsi siswa terhadap pelajaran fisika melalui persamaan regresi $\hat{Y}=16,121+0,701 \mathrm{X}_{2}$. Persamaan regresi ini mengartikan bahwa setiap pertambahan nilai prediktor $X_{2}$ sebesar satu satuan maka nilai kriterium $Y^{\wedge}$ akan bertambah sebesar 0,701 satuan. Persamaan regresi yang didapatkan menggambarkan bahwa tinggi rendahnya prestasi belajar fisika siswa 
disebabkan oleh persepsi siswa terhadap pelajaran fisika yang diprediksi dengan persamaan regresi tersebut.

Berdasarkan Tabel 10, uji regresi ganda dua prediktor antara $X_{1}$ dan prediktor $X_{2}$ dengan kriterium $Y$ diperoleh nilai $F_{\text {hitung }}$ sebesar 324,97. Taraf signifikansi yang digunakan adalah 5\% dengan derajat kebebasan pembilang 2 dan derajat kebebasan penyebut 259 diperoleh nilai $F_{\text {tabel }}$ sebesar 1,9693. Jika $F_{\text {hitung }}$ dibandingkan dengan $F_{\text {tabel }}$ maka didapatkan $F_{\text {hitung }}>F_{\text {tabel }}$ (Ho ditolak dan Ha diterima). Hasil ini menunjukkan terdapat hubungan positif secara bersama-sama antara motivasi intrinsik dan persepsi siswa terhadap pelajaran fisika siswa kelas X MIPA SMA Negeri se-Kota Singaraja. Nilai $R^{2}$ ( $R$ Square) sebesar 0,717 menunjukkan bahwa $71,7 \%$ dari variabel prestasi belajar fisika dapat dijelaskan oleh perubahan variabel motivasi intrinsik dan persepsi siswa terhadap pelajaran fisika. Sumbangan efektif variabel $X_{1}$ dan $X_{2}$ secara bersama-sama terhadap $Y$ sebesar $12,91 \%$ dan $58,79 \%$ dengan akumulasi kedua prediktor sebesar $71,70 \%$ dan sisanya sebesar $28,3 \%$ merupakan akumulasi sumbangan dari variabel-variabel lain yang tidak dikaji dalam penelitian ini. Variasi kontribusi dari variabel prestasi belajar fisika dapat dijelaskan oleh variabel motivasi intrinsik dan persepsi siswa terhadap pelajaran fisika melalui persamaan regresi $\hat{Y}=14,468+0,127 \mathrm{X}_{1}+0,598 \mathrm{X}_{2}$. Persamaan regresi ini mengartikan bahwa setiap pertambahan nilai prediktor $X_{1}$ dan $X_{2}$ masing-masing sebesar satu satuan, maka nilai kriterium $Y^{\wedge}$ akan bertambah sebesar 0,127 satuan dan 0,598 satuan. Persamaan regresi ini menggambarkan bahwa tinggi rendahnya prestasi belajar fisika disebabkan oleh motivasi intrinsik dan persepsi siswa terhadap pelajaran fisika yang diprediksi dengan persamaan regresi tersebut.

Berdasarkan hasil penelitian, diketahui bahwa motivasi intrinsik memiliki hubungan yang positif dan signifikan dengan prestasi belajar fisika siswa. Hasil pengujian hipotesis pertama didapatkan nilai $\beta$ sebesar 0,588 atau $\beta>0$ yang artinya terdapat hubungan positif dan signifikan antara motivasi intrinsik terhadap prestasi belajar fisika siswa kelas X MIPA SMA Negeri se-Kota Singaraja. Motivasi intrinsik memberikan dorongan belajar yang paling baik untuk siswa belajar (Aini, 2017). Siswa tidak memerlukan imbalan terlebih dahulu untuk belajar (Akhtar, 2017). Siswa yang memiliki motivasi dalam diri mampu memilih gaya belajar yang digunakan (Bosch, 2019). Siswa yang bisa menentukan gaya belajarnya dapat mengetahui apa yang harus dilakukan untuk mencapai prestasi. Motivasi intrinsik yang tinggi untuk belajar menimbulkan hasrat dan keinginan untuk berhasil mencapai prestasi yang diinginkan siswa. Siswa akan terdorong untuk belajar lebih giat demi mencapai apa yang di cita-citakan. Oleh karena itu, motivasi intrinsik berkontribusi dalam meningkatkan prestasi belajar siswa.

Berdasarkan hasil penelitian, diketahui bahwa persepsi siswa terhadap pelajaran fisika mempunyai hubungan positif dan signifikan dengan prestasi belajar fisika siswa. Hasil pengujian hipotesis kedua didapatkan bahwa nilai $\beta$ sebesar 0,701 atau $\beta>0$ yang artinya terdapat hubungan positif dan signifikan antara persepsi siswa terhadap pelajaran fisika terhadap prestasi belajar siswa kelas XMIPA SMA Negeri se-Kota Singaraja. Menurut Mawarnia (2017) siswa yang memiliki persepsi yang baik terhadap pembelajaran akan membuat siswa lebih perhatian. Menurut Kurniawan (2016). Persepsi siswa terhadap mata pelajaran fisika merupakan faktor intrinsik siswa yang memengaruhi prestasi belajar fisika. Oleh karena itu, persepsi siswa terhadap pelajaran fisika berkontribusi dalam meningkatkan prestasi belajar siswa. Oleh karena itu, persepsi siswa terhadap pelajaran fisika berkontribusi dalam meningkatkan prestasi belajar siswa.

Berdasarkan hasil penelitian, diketahui bahwa motivasi intrinsik dan persepsi siswa terhadap pelajaran fisika mempunyai hubungan positif dan signifikan dengan prestasi belajar fisika siswa. Hasil pengujian hipotesis ketiga didapatkan bahwa nilai $\beta$ bernilai 0,127 pada motivasi intrinsik dan 0,598 pada persepsi siswa terhadap pelajaran fisika atau $\beta>0$ yang artinya terdapat hubungan positif dan signifikan secara bersama-sama antara motivasi intrinsik dan persepsi siswa terhadap pelajaran fisika siswa kelas X MIPA SMA Negeri seKota Singaraja. Siswa yang memiliki motivasi dan persepsi baik terhadap pelajaran dapat mencapai prestasi belajarnya (Yovitasae, 2018). Siswa yang memiliki persepsi baik terhadap pelajaran akan senang melakukan aktifitas belajarnya (Azka, 2018). Berdasarkan uraian 
Jurnal Pendidikan Fisika Undiksha, Vol. 10 No.1, Juli 2020

p-ISSN : 2599-2554 (Print), e-ISSN : 2599-2562 (online)

tersebut, motivasi intrinsik dan persepsi siswa terhadap pelajaran memiliki hubungan positif dan berkontribusi dalam meningkatkan prestasi belajar fisika.

\section{SIMPULAN DAN SARAN}

\section{Simpulan}

Motivasi instrinsik siswa dan persepsi mereka terhadap mata pelajaran fisika sangat menentukan hasil belajar mereka. Studi terhadap hubungan antara motivasi instrinsik, persepsi siswa terhadap fisika dan hasil belajar fisika pada siswa kelas X MIPA SMA Negeri di kota Singaraja menunjukkan bahwa (1) Terdapat hubungan positif dan signifikan antara motivasi intrinsik dengan prestasi belajar fisika siswa kelas X MIPA SMA Negeri se-Kota Singaraja dengan sumbangan efektif sebesar $12,67 \% \%$; (2) Terdapat hubungan positif dan signifikan antara persepsi siswa terhadap pelajaran fisika dengan prestasi belajar fisika siswa kelas X MIPA SMA Negeri se-Kota Singaraja dengan sumbangan efektif sebesar 59,03\%; (3) Terdapat hubungan positif dan signifikan secara bersama-sama antara mitivasi intrinsik dan persepsi siswa terhadap pelajaran fisika dengan prestasi belajar fisika siswa kelas X MIPA SMA Negeri se-Kota Singaraja dengan sumbangan efektif sebesar $71,70 \%$.

\section{Saran}

Untuk meningkatkan prestasi belajar, guru hendaknya mengembangkan atau memunculkan motivasi intrinsik siswa dan persepsi positif siswa terhadap mata pelajaran fisika. Di samping faktor motivasi instrinsik dan persepsi siswa terhadap mata pelajaran, hasil belajar fisika siswa juga ditentukan oleh faktor lain yang tidak diteliti dalam penbelitian ini, oleh karena itu faktor-faktor lain ini dapat dijadikan sebagai kajian oleh para peneliti lainnya.

\section{UCAPAN TERIMA KASIH}

Peneliti mengucapkan terima kasih yang ditujukan kepada Prof. Dr. Ketut Suma, M.S. selaku pembimbing I, Drs. Iwan Suswandi, M.Si. selaku pembimbing II, I Putu Eka Wilantara, M.Pd. selaku kepala SMA Negeri 1 Singaraja, Drs. I Made Arya Kartawan, M.Pd. selaku kepala SMA Negeri 2 Singaraja, Made Sri Astiti, S.Pd., M.Pd. selaku kepala SMA Negeri 3 Singaraja, dan Putu Gede Wartawan, S.Pd., M.Pd. selaku kepala SMA Negeri 4 Singaraja yang telah memberikan izin kepada penulis untuk melaksanakan penelitian di sekolah yang dipimpinnya.

\section{DAFTAR RUJUKAN}

Aini, Q., Mawardi, \& Rizkiawati, B. Y. (2017). Pengaruh motivasi intrinsik dan ekstrinsik terhadap prestasi mata pelajaran ekonomi. Jurnal IImu Kependidikan, 12(1), 59-64. Tersedia pada http://dx.doi.org/1 0.29408/edc.v12i1.1323. Diakses 13 Oktober 2019.

Akhtar, S. N., lqbal, M., \& Tatlah, I. A. (2017). Relationship between intrinsic motivation and students' academic achievement: A secondary level evidence. Bulletin of Education and Research, 39(2), 27-28. Tersedia pada https://eric.ed.gov/?id=EJ1210159. Diakses 09 Oktober 2019

Albadi, N. M., Harkins, J., \& O'Toole, J. M. (2018). Recent reforms in saudi secondary science education teacher and student perceptions of grade 10 physics. International Journal of Sci and Math Educ, 17(4), 716. Tersedia pada https://doi.org/10.1007/s10763-018-9881-3. Diakses 07 Oktober 2019.

Arief, H., S. (2016). Meningkatkan motivasi belajar melalui pendekatan problem based learning (PBL). Jurnal Pena IImiah, 1(1), 142. Tersedia pada https://doi.org/10.23819/pi.v1i1.2945. Diakses tanggal 23 Maret 2019.

Arif, A. (2016). Hubungan persepsi siswa pada mata pelajaran dengan prestasi belajar fisika di SMAN 4 Banda Aceh. Jurnal Ilmiah Mahasiswa Pendidikan Fisika 1(3) 2. Tersedi 
pada http://www.jim.unsyiah.ac.id/pendidikan-fisika/article/view/216. Diakses

Desember 2019.

Azka, R. (2019). Hubungan motivasi belajar dan persepsi siswa terhadap pelajaran fisika dengan prestasi belajar matematika. Jurnal Pengembangan Pembelajaran Matematika, 1(1), 23-29. Tersedia pada http://ejournal.uin-suka.ac.id/saintek/jpm/article/view/1358. Diakses 13 Oktober 2019.

Bosch, C., Mentz, E., \& Reitsma, G.M. (2019). Integrating cooperative learning into the combined blended learning design model: Implications for students' intrinsic motivation. International Journal of Mobile and Blended Learning, 11 (1), 59. Tersedia pada https://doi.org/10.4018/IJMBL.2019010105. Diakses 17 Februari 2019.

Diana, W. K., Mardana, I. B. P., Suwindra, I. N. P. (2018). Prestasi belajar fisika siswa kelas X mipa sma negeri se-kecamatan nusa penida tahun pelajaran 2018/2019. Jurnal Pendidikan Fisika Undiksha, 8(2), 4. Tersedia pada https://ejournal.undiksha.ac.id/index.php/JJPF/article/ view/20631/0. Diakses 16 Juni 2020.

Indriawati, P. (2018). Pengaruh kepercayaan diri dan kecerdasan emosional terhadap hasil belajar mahasiswa Universitas Balikpapan. Jurnal Pendidikan Edutama, 5(2): 1-10. Tersedia pada http://dx.doi.org/10.33373/dms.v7i1.1633. Diakses 19 Oktober 2019.

Kemendikbud. (2003). Undang-undang nomor 20 Tahun 2003 tentang sistem pendidikan nasional. Tersedia pada https://kelembagaan.ristekdikti.go.id/wp-content/uploads/2 016/08/UU no 20 th 2003.pdf. Diakses 19 Oktober 2019.

Kurniawan, A., \& Sumadi (2016). Hubungan antara persepsi siswa terhadap fisika, kemandirian belajar dan fasilitas belajar dengan prestasi belajar fisika. Jurnal IImiah Pendidikan Fisika, 3(2), 65-66. Tersedia pada http://jurnal.ustjogja.ac.id/ind ex.php/COMPTON/article /view/686. Diakses 06 November 2019.

Lestari, I.A., Hermansyah, A., \& Rohiat, S. (2017). Hubungan persepsi siswa kelas X MIPA di SMA Negeri Sekota Bengkulu tahun ajaran 2016/2017 tentang variasi gaya mengajar guru dengan hasil belajar kimia. Jurnal Pendidikan dan IImu Kimia, 1(2), 114-115. Tersedia pada https://ejournal.unib.ac.id/index.php/alotropjurnal/article/view/3525. Diakses 09 Oktober 2019.

Marupa, D. (2017). Hubungan antara persepsi gaya mengajar guru dalam pembelajaran fisika dengan motivasi belajar siswa Kelas XI IPA di SMA Negeri 7 Medan. (Skripsi online). Tersedia pada http://repository.uma.ac.id/bitstream/123456789/85 68/1/138600100.pdf. Diakses 16 Oktober 2019.

Mawarnia, B. (2017). Pengaruh biaya pribadi (private cost) dan persepsi siswa tentang pembelajaran ekonomi materi akuntansi terhadap hasil belajar siswa SMA. Jurnal Ekonomi Pendidikan dan Kewirausahaan 5(1) 93-100. Tersedia pada http://dx.doi.org/ 10.26740/jepk.v5n1.p91-104. Diakseks 06 November 2019.

Moekijat. (2002). Dasar-dasar motivasi. Bandung: CV. Pionir Jaya Bandung.

OECD. (2019). PISA 2018 insight and interpretations. Tersedia pada https://doi.org /10.1787/5f07c754-en. Diakses 14 Januari 2020.

Permendikbud Republik Indonesia Nomor 69. (2013). Tentang kerangka dasar dan struktur kurikulum Sekolah Menengah Atas/Madrasah Aliyah. Tersedia pada http://bsnpindonesia.org/2013/06/20/permendikbud-tentang-kurikulum-tahun-2013/. Diakses 06 November 2019.

Prasetyowati, D. W., \& Budhi, W. (2017). Hubungan antara persepsi siswa perhatian selama pembelajaran dan kecemasan sebelum tes dengan prestasi belajar. Jurnal IImiah 
Pendidikan Fisika 4(1) 92-98. Tersedia pada http://www.jurnal.usti ogja.ac.id/index.php/COMPTON/article/view/1390/0. Diakses 06 November 2019.

Pratama, Y. M., Iswari, R. S., \& Ngabekti, S. (2018). Korelasi persepsi dan minat dengan hasil belajar siswa kelas 10 lintas minat biologi SMAN 1 Ambarawa. Jurnal Pendidikan MIPA 8(1) 63. Tersedia pada http://dx.doi.org/10.21580/phen.2018.8.1.2183. Diakses 06 November 2019

Saki, K., \& Nadari, M. (2018). The relationship between self-regulated learning, academic self-concept and the academic achievement motivation of students in the second grade of high school. Journal of Family Medicine 16(2) 328. Tersedia pada https://plat form.almanhal.co m/Files/Articles/117401. Diakses 22 Mei 2020.

Santyasa, I. W. (2018). Metodologi penelitian pendidikan. Singaraja: Undiksha Pres

Slameto. (2003). Belajar dan faktor-faktor yang mempengaruhinya. Jakarta: PT Rineka Cipta

Suprapto, N. (2019). Development and validation of students' perception on learning by questioning scale in physics. International Journal of Instruction, 12(2), 254. Tersedia pada https://doi.org/10.29333/iji.20 19.12216a. Diakses 07 Oktober 2019.

Suprihatin, S. (2015). Upaya guru dlam meningkatkan motivasi belajar siswa. Jurnal Program Studi Pendidikan Ekonomi 3(1) 81. Tersedia pada http://dx.doi.org/10. 24127/ja.v3i1.144. Diakses 27 Desember 2019.

Utami, P. R. A., Santyasa, I. W., Rapi, N. K. (2018). The relationship between learning motivation and emotional intelligence with physics learning achievement of public high school students Class XI MIA in Singaraja City. Education end Learning Journal, 25(1), 28. Tersedia pada http://journal2.um.ac.id/index.php/jpp/article/view/8141. Diakses 16 Juni 2020.

Yovitasae, M., Djazari, M. (2018). Pengaruh persepsi siswa tentang metode mengajar guru, motivasi belajar, dan lingkungan teman sebaya terhadap prestasi belajar akuntansi keuangan siswa kelas XI Akuntansi SMK Negeri 7 Yogyakarta tahun ajaran 2017/2018. Jurnal Pendidikan Akuntansi Indonesia, 16(2), 46-56. Tersedia pada https://doi.org/10.21831/jpai.v16i2.22052. Diakses 13 Juni 2019. 